\title{
Push Out or Drop Out? Taking a Critical Look at the Poor Performance and Drop-Out of Students of the JSS/JHS Programme in Ghana
}

\author{
Charles Gyan \\ Department of Social Work, University of Ghana \\ P. O. Box LG419, Legon-Accra. \\ charlesgyan@live.com \\ Matthew Gmalifo Mabefam \\ Department of Social Work, University of Ghana \\ P. O. Box LG419, Legon-Accra \\ gmalifo@yahoo.com \\ Michael Baffoe, M.S.W, Ph.D \\ Associate Professor, Faculty of Social Work, University of Manitoba \\ Winnipeg, Manitoba, Canada R3T 2N2 \\ michael.baffoe@ad.umanitoba.ca
}

Doi:10.5901/ajis.2014.v3n1p409

\begin{abstract}
In 1974, new educational reforms aimed at laying a solid educational foundation for children were launched in Ghana. Amongst other things, the reforms recommended the establishment of a three-year Junior Secondary School (JSS) system later renamed the Junior High School system which sought to provide more practical educational skills to students. It aimed to be proactive to the needs of Ghanaians by introducing pre-technical and pre-vocational skills to empower pupils with skills to work with after completion of the JHS program if they are not academically inclined to go further through the Senior Secondary/Senior High School system. After several years of implementation, the success rates of students from the JSS/JHS system have been abysmally poor. The situation is even more abysmal in the rural areas of Ghana where most schools lack basic teaching and learning tools. This paper, from a study of some JSS/JHS schools in some rural and urban settings in Ghana, takes a critical look at some of the factors in this educational system that has pushed many pupils to drop out of the school system hence making the system ineffective and incapable of meeting its intended purpose.
\end{abstract}

Keywords: Ghana; school drop-out; school completion; push-outs; educational reforms; Social Capital; High School

\section{Introduction}

Every nation's children are its future assets: its future workers, citizens, and leaders. It is widely recognized that education is the major tool by which people are empowered and thus be able to achieve social, economic and personalwell-being. As Greenberg et al. (2003) point out, the mission of every educational system should be to offer top-quality education to students to equip them to become knowledgeable, responsible, socially skilled, healthy and be productive contributing members of society. A dysfunctional or under-resourced educational system of any country diminishes its potential to deliver quality education to its youth and thus reducing their chances of earning the skills needed to improve the social and economic status. A high school drop-out rate in any educational system diminishes the pool of future qualified workforce. It has deep and wide-ranging impact on the economy of a nation. The current Ghanaian educational system is known to record very low academic performance rates since its inception over two decades ago. The goal of this study therefore is to explore the reasons that are responsible for such abysmal performance that undermine the purpose of the Junior High School (JHS) programme in Ghana.

To achieve this goal we will explore some of the current literature on school dropout. The qualitative methodology and conceptual framework used in conducting and analyzing the results of the study will be presented. Next we will highlight some of the factors that were highlighted in the study as contributing factors for the abysmal performance of the 
system that contributes to the high student dropout rates. We will then provide some narratives from some of the study participants to highlight their views of the causal factors enumerated. We will then discuss the findings, present some concluding thoughts and recommendations on ways to revamp the system for the benefit of its intended beneficiaries.

For the purpose of this study, dropout from the Junior High School system in Ghana may be considered as a student who not because of ill-health or unforeseen circumstances, did not enroll at the beginning of the current regular academic year or did not complete the regular academic year and did not come back the following year due to a combination of non-personal factors which impacted his/her motivation or ability to continue.

\section{Dropping Out of School}

Dropping out of school means leaving a school for practical reasons, necessities, or disillusionment with the school system from which the individual in question leaves. Most commonly, dropping out refers to a student quitting school before he or she graduates from the level or system he/she is enrolled in (Russell, 2001). When students leave school, it is usually not a decision they made overnight. Typically it is a process that happens over time. The reasons are varied and may include: to find employment, avoid bullying, family emergency, poor grades, depression and other mental illnesses, unexpected pregnancy, bad environment, lack of freedom, and boredom from lack of lessons relevant to their desired occupations. The consequences of dropping out of school can have long-term economic and social repercussions. Students who drop out of school in Ghana are more likely to be unemployed, homeless, and may end up on the wrong side of the law leading to possible incarceration.

\section{Pre \& Post-Colonial Education Structure in Ghana}

The Ghanaian educational system after independence continued to follow the structure that was left by the British Colonial Administration. Thus, even on the attainment of independence, Ghana still followed the educational structure that was bequeathed on it during the period of colonialism (Okyerefo, Fiaveh, \& Lamptey, 2011). Ghana's pre-university educational system after the attainment of independence in 1957 continued to be of 17-year duration. It was composed of 6 years primary, 4 years middle school, 5 years secondary school and 2 years preuniversity preparatory course (Okyerefo, Fiaveh, \& Lamptey, 2011). That is a 6-4-5-2 educational structured. Just like its predecessor-colonial education - post-independent education continued to be academic oriented in nature (Ocansey, Seidu \& Jatong, 2013).

Ghana's educational structure has gone through several reviews and reformations since the colonial era. These reforms are done to improve the educational system taking into consideration the lapses that have been noted in the previous structures. For instance, Frimpong (2000) asserts that the old system inherited from the colonial authorities has been subjected to public criticisms for being too academic in the sense that, it did not train people to acquire practical skills to establish themselves on completion of their courses. This made it difficult for the educational system to respond favorably to the country's man power and developmental needs.

As a result of this, Ghana in 1987 restructured her educational system aimed to reflect the true cultural, socioeconomic and man power needs of the nation (Ministry of Education, 1999). The new reforms mooted the introduction of pre-technical and pre-vocational subjects, an attempt to make the JSS curriculum comprehensive and to cater for all talents and provide them with practical skills where they could work after JHS completion. In view of this the following were among the objectives established by the1987 reforms:

- The child should acquire employable skills such as carpentry, pottery, baskets weaving, catering among others

- The child should be self-employed if he/she could not get access to further studies so as to earn a living

In 2007, the current Junior and Senior High School system was born out of the report of the Anamuah-Mensah committee (Education Reform, 2007). The structure of the educational system includes two (2) years of Kindergarten education as part of Basic Education and Apprenticeship training for leavers of the Junior Secondary School who are unable to or do not want to continue in the formal sector (MoE, 2002); three (3) years Junior High School and three (3) years Senior High School (Education Reform, 2007). That is 2-6-3-3 educational structure. The major objectives of the current educational structure were: "formation of human capital for industrial growth and for ensuring competitiveness in the global economy; ability to make use of recent developments in Science and Technology, especially Information and Communication Technology (ICT); radical transformation in the field of work and employment; and the preservation of cultural identity and traditional indigenous knowledge and creativity" (MoE, 2002, p3). The reform was intended to enhance children's access to basic education, revitalize technical/vocational education and training and improving the quality of instruction and ensuring inclusive education (MoE, 2002). 
However, from the very inception of the new system, it has been noted that the Junior Secondary School (now JHS) kicked off with a lot of challenges as revealed by the first batch of the Basic Education Certificate Examination (B.E.C.E) results released by the West African Examination Council (W.A.E.C) in 1990. The results indicated that, less than half of the number of students who sat for the examination made aggregate 24 or better (Chief Examiner's Report, 1990). However, the ability of students to enter Senior Secondary school is dependent on their performance at the Basic Education Certificate Examination. What this means is that, if students do not do well in the B.E.C.E, they may not be able to proceed and hence will be pushed out or drop out of school signifying the end of their academic journey.

Sound educational system is the bedrock of the development of every country including Ghana. But as it stands now, Ghana is struggling to gain its feet when it comes to education as a result of the number of children who are not enrolled in school and those who have dropped out of school as a result of low or non-performance at the Basic Education Certificate Examinations (B.E.C.E). The poor academic performance manifested in the results obtained at the end of the B.E.C.E organized by West African Examinations Council (WAEC) is usually very bad. This denies a lot of student's access to the Senior High School system (SHS).

Evidence available shows a remarkable drop in the academic performance of JHS in Ghana especially the public schools over the last decade (Etsey et al., 2005). For instance, over 34 public schools recorded 0\% pass rate in the 2008 and 2010 Basic Education Certificate Examination (GNA, 2009 \& 2010 as cited in Okyerefo et al, 2011). According to Okyerefo et al (2011) by implication no pupil from these public schools was able to gain admission to Senior High School (SHS). Okyerefo and his colleagues noted that, this trend in the (B.E.C.E) has been ongoing for several years in the public schools, especially those in rural Ghana and if these trends continue, Ghana may not be able to achieve the Millennium Development Goal of universal education.

\section{Methodology}

Using a qualitative research design, this phenomenological study took a narratological research approach that focused on collecting the lived experiences of school dropouts from Ghana's Junior Secondary School system within a social capital framework (McNeal, 1999). The context of this study was selected communities in the Northern and Ashanti regions of Ghana. The Northern Region was purposely chosen because of its noted and documented poor academic performance in the Basic Elementary Certificate Examination (B.E.C.E), the graduating Certificate examinations of the Junior Secondary School system. The Ashanti Region on the other hand was chosen because it mirrors a typical highperforming region in the B.E.C.E in Ghana.

Triangulation of data sources included field notes, interviews with the participants, and archival documents. The qualitative research approach was the preferred methodology because as Creswell (2009) claims, qualitative research helps researchers identify "the essence of human experiences about a phenomenon as described by participants" (p. 13). The qualitative approach is concerned with meaning, and how it informs subjective understanding (Hollway and Jefferson, 2000). Thus, the researchers' adoption of this approach offered them the opportunity to capture the experiences of parents, teachers, and students about the factors responsible for the poor performance of the JHS and also stressed the importance of context, setting and participants' frame of reference to the subject matter under investigation (Marshall \& Rossman, 2006). The total sample size of the study was sixty-eight (68) participants comprising the following:

Forty (40) continuing students (five from each of the eight selected schools);

Eight (8) Headteachers (one from each school);

Eight (8) teachers (one from each school);

Eight (8) former "graduates" of the system (two from each of the eight schools

Both probability and non-probability sampling techniques were used. Simple random sampling was used to select the two regions. The country was divided into two zones. These zones include:

- The Northern zone (Northern, Upper East, Upper West Regions, Brong-Ahafo and Volta Region)

- Southern zone (Ashanti, Greater Accra, Western, Central, and Eastern Regions).

The Southern Zone has been known for high performances of students in the JHS system while the most schools in the Northern Sector are known to record low performance rates. The intention in the study therefore was to have equal number of JHS participating schools from both zones. A Purposive sampling technique was therefore used to select four Junior High Schools (JHS) in each of the regions selected within the zones (Berg, 2001). These schools mirrored the typical rural JHS whose results can be used for to gauge a picture of the performance of the JHS system in Ghana. This is because the JHSs selected have similar characteristics with other JHSs across the country. With regards to 
participants for the study, purposive sampling technique was again used. This was used because it enabled the researchers to identify key people with much knowledge to help find reasons for the poor performance of the JHS programme in Ghana.

\section{Research Questions}

The study sought to find answers to the following research questions:

1. What is the general trend of performance of students in the JHS system in Ghana?

2. How do social capital in terms of household and community factors contribute to the poor performance of students in the JHS programme in Ghana?

3. How does the availability or non-availability of resources, and factors within the school environment contribute to the poor performance of students in the JHS system in Ghana?

\section{Study Limitations}

This qualitative study was limited in its scope of inquiry. It was intended to seek an initial snapshot of the problem of high dropout rates of students from Ghana's Junior High School system. For the purposes of this study therefore, general limitations of phenomenological qualitative study may make transferability of the results of this study restricted to school systems similar to the ones in which these students were enrolled (Hollway, \& Jefferson, 2000). Although the methodology associated with qualitative research elicits rich, in-depth responses (Creswell, 2009), the information gathered was not intended to represent the views of other junior high school dropouts in other regions. The location for the study, a number of rural and urban setting schools, should be kept in mind when trying to extrapolate the results to another area. The information elicited from the individuals participating in the study was limited to that which they were willing to reveal.

\section{Conceptual Framework}

The study utilized the Social capital Theory as a Framework for its analysis. Social Capital in the Creation of Human Capital was used, to discuss the relationship between social capital and dropout rates. As defined by Coleman (1988), Social capital includes multiple concepts. Each of the included concepts produces a desirable outcome within a relationship among different people. Each person included in the relationship places value on the desired outcome. This value is the intangible resource that Coleman refers to as social capital.

According to Coleman (1988), the most basic components of social capital are the numerous relationships and interactions among various people who are associated with one another. Within the setting of education, these interactions may take various forms, including dropouts, parent-child interactions, parent-school interactions, child-school interactions, and parent-parent interactions. Multiple overlapping interactions whereby parents develop relationships with the parents of their children's friends are known as intergenerational closure (Carbonaro, 1998).

Other important components of social capital are norms and sanctions developed through relationships (Coleman, 1988). Norms and sanctions provide a rationale for certain actions, promoting some and inhibiting others. Within the confines of relationships, rewards and consequences are established based on the accepted value placed on the actions of the parties within the relationships. In 1988, Coleman brought many social factors together to define social capital and how it is related to dropout rates. He found that as the level of social capital increased, a student's tendency to drop out of school decreased.

The final components of Coleman's (1988) definition of social capital are trust and obligations. As a high level of trust is recognized by parties within the same network, support and positive interactions are established. Within relationships in the network, expectations of reciprocity evolve from the interactions and the development of trust and obligations arises. The expectations of reciprocity promote actions within the relationships that result from the feelings of obligation. In the context of this study, obligations falls on the authorities that are responsible for providing the needed resources including support and encouragement for the students to succeed in school. Coleman (1988) maintains that social capital is an aggregate of trust and obligations developed within networks of various people. It is a resource available to individuals, much like monetary capital. The obligations form a type of social credit. A variety of social circumstances that influence a student's tendency to drop out of high school may be related to the level of social capital found in a student's family, school, or community. 
Many researchers concur in their conclusions that school attendance improved with increased networking among school personnel, parents, students, and community members because levels of social capital increased (Epstein \& Sheldon, 2002; Hofferth et al., 1998; Israel \& Bealieu, 2004; McNeal, 1999; Yan, 1999). Furthermore, strengthening social capital within communities has been shown to have an association with a decrease in dropout tendency within the community (Israel \& Beaulieu, 2004). Recent studies have shown that high parental expectations are associated with a decrease in the tendency to drop out of school (Astone \& McLanahan, 1991; Israel \& Beaulieu, 2004). The above reflect the current Ghanaian situation where networking and collaboration are lacking among the various stakeholders in the educational field namely school personnel parents, students, community members, and government. Finally, school social capital has been associated with an increase in student achievement and a decrease in dropout rates (Israel \& Beaulieu, 2004).

\section{Findings/Results}

The results are organized in three major sections. The first section presents the general trends in the performance of students in the selected JHS as measured by their performance in school and national examinations. The second section presents the findings on the household factors that contribute to the poor performance of JHS students in Ghana. The third section presents the results on in-school factors that underwrite the poor performance of JHS students in Ghana.

\subsection{Performance Trend of the selected Schools in the Basic Education Certificate Examination}

Available statistics show that Northern and southern schools' performance is non-comparable at the BECE in Ghana (MoE, 2002). This is presented in the tables below:

Table 1: The Performance rate of Junior High Schools (JHS) in the Southern part of Ghana

\begin{tabular}{|c|c|c|c|c|c|c|c|c|}
\hline \multirow{2}{*}{ Aggregate Range } & \multicolumn{2}{|c|}{ Kyerekrom M/A JHS } & \multicolumn{2}{c|}{$\begin{array}{c}\text { Akrokerri R/C } \\
\text { JHS }\end{array}$} & \multicolumn{2}{c|}{$\begin{array}{c}\text { Akrokerri Methodist } \\
\text { JHS }\end{array}$} & $\begin{array}{c}\text { Ebenezer Methodist } \\
\text { JHS }\end{array}$ \\
\cline { 2 - 9 } & 2010 & 2011 & 2010 & 2011 & 2010 & 2011 & 2010 & 2011 \\
\hline $6-12$ & 0 & 0 & 0 & 0 & 0 & 0 & 9 & 0 \\
\hline $13-18$ & 6 & 0 & 6 & 1 & 3 & 0 & 8 & 0 \\
\hline $19-24$ & 19 & 7 & 15 & 2 & 13 & 1 & 0 & 2 \\
\hline $25-30$ & $14\left(8^{\star}\right)$ & 17 & $21\left(19^{\star}\right)$ & 8 & $7\left(3^{*}\right)$ & 5 & 0 & 13 \\
\hline $31+$ & 2 & 26 & 1 & 35 & 0 & 21 & 0 & 3 \\
\hline T.C. P2 & 41 & 50 & 43 & 46 & 20 & 27 & 17 & 18 \\
\hline No. Failed & 10 & 26 & 20 & 35 & 3 & 21 & 0 & 3 \\
\hline
\end{tabular}

As Table 1 above shows, the performance of the students in BECE, whether rural or urban, the selected schools in the south have performance rate of a minimum of $48 \%$ and a maximum of $100 \%$ pass.

In the Northern part of Ghana, it is evident from the study that students' performance is poor. As table 2 below shows, for the three years, from 2009 to 2011, students have consistently performed more poorly. For example, of the 132 students presented by the St. Joseph JHS for the Basic Education Examination in 2010, 116 candidates representing 87.9 percent failed. Table 2 below therefore presents the proportion of students who passed and failed BECE between 2010 and 2011.

\footnotetext{
${ }^{1}$ A nine-point scale is used in grading the candidates with Grade 1 denoting the highest performance and Grade 9 the lowest. A pass in $B E C E$ is defined as gaining an aggregate range of 6-30 in the best six subjects with a grade 5 or better in the core subjects (i.e. Mathematics, English, Integrated Science and Social Studies). * It indicates a change in the grading system for 2010/2011 academic year where five subjects instead of six were used. Thus, those with the asterisk are those who failed based on the revised aggregate cutoff point for admissions into the Senior High Schools.

2 It denotes the total number of candidates presented in each particular year 
Table 2: The Performance rate of JHSs in the Northern part of Ghana

\begin{tabular}{|c|c|c|c|c|c|c|c|c|}
\hline \multirow{2}{*}{ Aggregate Range $^{3}$} & \multicolumn{2}{|c|}{ St. Joseph JHS } & \multicolumn{2}{c|}{ Chamba L/A JHS } & \multicolumn{2}{c|}{ Sogon No 2 JHS } & \multicolumn{2}{c|}{ Morning Star JHS } \\
\cline { 2 - 9 } & 2010 & 2011 & 2009 & 2010 & 2010 & 2011 & 2010 & 2011 \\
\hline $6-12$ & 0 & 0 & 0 & 0 & 0 & 0 & 0 & 0 \\
\hline $13-18$ & 1 & 1 & 0 & 0 & 0 & 2 & 5 & 0 \\
\hline $19-24$ & 12 & 13 & 5 & 1 & 5 & 19 & 30 & 0 \\
\hline $25-30$ & $20\left(16^{*}\right)$ & 7 & 31 & $17\left(14^{*}\right)$ & $19^{*}$ & 28 & $3\left(1^{*}\right)$ & 4 \\
\hline $31+$ & 100 & 101 & 74 & 73 & 4 & 6 & 0 & 63 \\
\hline T.C. P4 & 132 & 122 & 110 & 91 & 28 & 55 & 38 & 67 \\
\hline No. Failed & 116 & 101 & 74 & 87 & 23 & 6 & 1 & 63 \\
\hline
\end{tabular}

The problem of poor performance among students of JHS is influenced by several factors. This section presents the findings of household factors that affected students' performance at the JHS level. To this effect, it was realized that, the characteristics of a particular household influenced the performance of students of that household. Among some of the household factors identified to have affected performance were economic statuses of the parents, household size, fees and indirect cost of schooling, educational level of parents, health of household members, among others.

Firstly, the findings of this study showed that students who come from low economic status households perform poorly in the JHS examinations. During the interview, one of the parents was captured saying

"If I cannot afford for my basic necessities such as food, clothing and a sleeping place, I would find it difficult to cater well for my children in school. In situations like this I leave them to fend for themselves because education is secondary in relation to my current needs."

The study found out that children who are hungry, thirsty, do not have uniforms or in tattered uniforms will not feel comfortable and happy in school. This will definitely affect their academic performances because they do not have the peace of mind to concentrate on their academic work.

Again, the findings of the study indicate that households with large number of children in school find it difficult to cater for all of them thereby affecting the performance of the children and a possible drop out from school. A parent respondent had this to say

"I have four wives, and 10 children for now, how do I take care of all these children in school...I expect them to go with me to the farm everyday but instead they say we should send them to school, how do I alone farm to feed such a large family and take care of their needs in school?"

Also, it was found out in the study that, some children were in school and at the same time working to take care of themselves in school. Situations like these compel some of them to absent themselves from school to go and labor (by day) to be able to meet their needs in school. This was confirmed by a JHS graduate who shared his experience with us:

\begin{abstract}
"I remember that when I was in school, I had to go looking for money to buy books, food, uniforms among others. This is because we were four siblings in a class and my parents did not have money to take care of us in school and since we needed to go to school we had to absent ourselves sometimes from school to go for "by day" to survive...this affected us seriously and led to our poor performance at the end of the B.E.C.E."
\end{abstract}

Furthermore, parents' educational status was found to be very crucial when it comes to children's performance in JHS examinations. It was realized that, though performance is generally poor, children from educated parents did better

\footnotetext{
${ }^{3}$ A nine-point scale is used in grading the candidates with Grade 1 denoting the highest performance and Grade 9 the lowest. A pass in $B E C E$ is defined as gaining an aggregate range of 6-30 in the best six subjects with a grade 5 or better in the core subjects (i.e. Mathematics, English, Integrated Science and Social Studies). * It indicates a change in the grading system for 2010/2011 academic year where five subjects instead of six were used. Thus, those with the asterisk are those who failed based on the revised aggregate cutoff point for admissions into the Senior High Schools.

${ }^{4}$ It denotes the total number of candidates presented in each particular year 
than those from non-educated parents. In confirmation with this, an educated parent had this to say:

I always help my children to do homework, collect their terminal examination papers to find where they did well and where they did not do well and this helps me identify their weaknesses and help them to improve their performance.

In a similar vein a non-educated parent had this to say:

I can neither read nor write, I don't know how my children perform in school. I am so busy with my farm work in such a way that I don't have time to visit them in school and meet with the teachers to find out their performance level. But why do I have to go the school to meet with teachers. They know their job. They are the one who should know whether the children are doing well or not and help them

Finally, it was revealed that the health status of members of the household is core in children's retention and performance in school. Children are sometimes taken out of school to take care of their sick relatives or to provide labor for the family farm since their parents are sick and do not have the strength to do so. This was mentioned during the field study as a reason accounting for poor performance of students of JHS in Ghana. This was illustrated by a female continuing student who says

I was withdrawn from school in form 2 to take care of my sick mum... after I had returned I could not follow my colleagues in class because they had covered a lot of things. This led to my poor performance in exams in the first term in form 3 examinations.

\section{In-School Factors that Contribute to Poor Performance of Students in Ghana}

School environments and factors have powerful influence on student's academic performance (Chitiavi, 2002). This suggests the capacity of the school to act as a last lifeline to students in the process of dropping-out. Several school factors have been revealed by the study as hampering the academic work and students' performance in Junior High schools in Ghana. To begin with, it was revealed that ineffective supervision of work in schools has negative repercussions on the performance of students. The study further revealed that most headteachers in public schools do not effectively supervise the teachers. A teacher participant in the study from the Northern Region posited that in their school

the headmaster comes to school twice every week and with these days he only stays in his office without even finding out what is going on in the school, whether teachers are teaching or not. This has also encouraged most of the teachers to absent themselves from school to embark on their private businesses with others using the students on their farms.

\section{A headteacher also indicated that}

I am the headteacher of my school as well as a full-time classroom teacher due to inadequate teachers. I find it difficult playing my headteacher role effectively because of the classroom work which takes much of my time. Combining my teaching role and strict supervision of my teachers becomes a very difficult task.

Again, it was clear that in most of the schools in the Northern region, academic facilities were not adequate and those available were in poor condition with walls having cracks, no ceiling and leaked roofings. A teacher remarked that:

Our school has problems with infrastructural development. Our classrooms are inadequate with some leaking. On a typical rainy day, the students have to be given a holiday since there is no safe structure for them to sit under. If the rain starts in the morning it presupposes that there would be no school that day and if it starts when we are in school then we are forced to close them.

With respect to computer training, it was found that most of these schools do not have computer laboratories for their students. The headmistress of Akrokerri Methodist JHS indicated that her school had no computer laboratory but her students rely on the community laboratory.

A teacher at Experimental Junior High school stated that "the teaching of ICT in this school is dominated by the teaching of facts rather than the acquisition of practical skills".

A student raised this concern: 
We are not fairly treated because some Junior High Schools have access to computers but we don't have. Switching on a computer is difficult for me. As a JHS three student preparing for my BECE and with ICT being one of our major subjects, computers are really important. I don't know what I am going to even write in the ICT exams.

Also, it was clear from the study that inadequate professional teachers affect the performance of students. The study revealed that most of the selected schools in the northern region had fewer professionally trained teachers than those in the Ashanti region. A headmistress raised this concern:

\begin{abstract}
My school has few permanent professional teachers, about $70 \%$ of my teachers every year are 'mentees ${ }^{5}$ ' who come and go after a year because of the presence of the training college in this community. Differences in the teaching styles and lack of continuity most often than not affect the studies and academic work of the students. These mentees use my school and other schools alike to learn teaching skills. At times some of these mentees involve themselves in gross misconduct which affects the performance of the students.
\end{abstract}

Moreover, limited teaching and learning materials was cited by participants as one of the major factors that contribute to the poor performance of students. With respect to text books, it was revealed that the schools had textbooks but the problem is with adequacy. One student opined that

Our English, Maths and Science books are not many. We therefore have to sit in pairs whenever we are treating topics which require the use of textbooks. At times individual assignments turn into group work since the books are not adequate

Furthermore, from the study, it was revealed that the JHS program is dominated by the learning of facts rather than acquisition of skills to make them employable due to the unavailability of needed materials for practicals in subjects such as vocational skills, technical skills and Agricultural science. A teacher stated that:

I am a catering teacher and due to lack of materials for practicals, students are often made to bring coalpots, utensils among others from their homes for practicals. At this part of this country, students are unable to get all the needed material for practicals thereby making the teaching of pre-vocational skills extremely difficult.

One headteacher reiterated this by indicating that

The re-introduction of school farms and life skills will be very beneficial. During our times, school farms and life skills; and the availability of equipment and materials needed helped in the acquisition of skills. These made the teaching and learning of these subjects more practical.

\title{
10. Discussion
}

A major finding from this study is that there is a great disparity between the performance of the students in BECE in the Northern and Southern parts of Ghana. It was clear that for the three years, from 2009 to 2011, students in the selected schools from the North have consistently performed more poorly. This finding is consistent with the findings of Okyerefo et al., (2011) that students' academic achievement in education is proportionally poor in the northern part of Ghana as compared to the South. This appalling performance among students of JHS is influenced by several factors (Etsey, 2005). To this effect, it was realized that, the characteristics of households influenced the performance of students of that household. Among some of the household factors identified to have affected performance were socio-economic statuses of the parents, household sizes, fees and indirect cost of schooling, educational level of parents, health of household members, among others.

Several authors have found household factors to be the one of the major contributory factors to the poor performance of students (Gubert and Robilliard, 2006; Ersado, 2005). Ainsworth et al., (2005); Connelly and Zhen, (2003); Duyea, (2003). Gubert and Robilliard (2006) found that children from low socio-economic households, and those that are vulnerable and prone to income shocks, commonly face some form of demand to withdraw from school if their parents cannot afford the direct or indirect costs of education. Etsey (2005) further indicated that the low economic status of parents may affect their ability to meet the needs of the child in school which invariably affect the child's level of

\footnotetext{
${ }^{5}$ Teacher trainees who are placed in schools in their final year to teach as part of their studies and are mentored by the head teachers of the various schools in which they are placed. 
concentration and also in the final round of his academic achievement. Ersado (2005) further supports this argument by advancing that parents' education is the most consistent determinant of child's participation and success in examinations. It has been documented that the higher the education of the parent or the household head, the greater the chances of increased access, regular attendance and lower dropout rates (Ainsworth et al., 2005; Connelly and Zhen, 2003; Duyea, 2003). Another dimension of the argument was put up by Case and Ardington (2004) when they indicated that girls are mostly affected when it comes to taking care of sick relatives because they are usually withdrawn out of school for long periods to take care of relatives to the detriment of their studies.

Several factors within the school environment and structure have the potential of affecting positively or negatively the educational performance and attainment of students (Chitiavi, 2002). Several school factors have been revealed by the study as hampering the academic work and students' performance in Junior High schools in Ghana. It was revealed from the study that ineffective supervision of work, domination of learning of facts rather than acquisition of new skills, infrastructural problems, teachers' work habit, limited teaching materials, inadequate textbooks and inadequate professionally-trained teachers were the spurs behind the abysmal failure of students in Ghana. This finding is in line with Chitiavi's (2002) study which shows that lack of proper supervision of teachers affects students' performance. He further argued that a headteacher who properly exercises his or her leadership responsibility will enable his or her school to realize good academic achievement.

The other side of the argument raised by several authors is the deleterious effect associated with overcrowding, noise exposure and the nature of school buildings on the performance of students (Earthman, 2004; Haines et al, 2001; Maxwell \& Evans, 2000). Schneider (2002) added that there is a positive relationship between the quality of school buildings and students' behavior. Further, positive attitudes towards studies are often influenced by the quality of the school's buildings and facilities (Schneider, 2002). Earthman (2004) also posits that school factors and students' performance are affected by lack of "adequate student capacity and appropriate acoustical conditions that are important factors in a school environment" (p.19).

Apart from the nature of facilities in schools, Farrant (1980) found that the professional skill of the teacher "establishes a productive classroom atmosphere from the start by means of good organization and carefully planned teaching structures" (p.5). This means that the services of professional teachers can impact positively on the academic performance of students. Farant (1980) further argues that professional competence often transforms into high quality of teaching which influence the learning of students.

\subsection{The Role of Government in the Poor Academic Performance of Junior High School Students in Ghana.}

The government of every country has a key role to play when it comes to education of its youth. We believe that it is every government's responsibility to ensure that its people, especially the youth have access to quality education. To achieve this, the educational system must have quality and adequate teaching and learning materials, infrastructure and other facilities, training and equitable distribution of teachers to all schools and a good remuneration to those manning the educational institutions to motivate them to perform their tasks (Mbugua, Kibet, Muthaa \& Nkonya, 2012; Munda, Tanui \& Kaberia, 2000; Pscharopolous \& Woodhall, 1985). Contrariwise, if governments fail to put premium on education and provide the school authorities with the needed resources, the outcome or performance of students and teachers are likely to be appalling.

The corroboration of the field result and literature reviewed had one thing in common. That is, the failure of students in Ghana's Junior High School system to achieve the optimum hinges on the central and local governments inability to provide them with the needed resources including human resources (teachers), materials (textbooks), and infrastructure (school buildings) (Mbugua, Kibet, Muthaa \& Nkonya, 2012; Pscharopolus \& Woodhall, 1985). Townsend (1999) points out that low educational attainment of most children in developing countries can be attributed to governments' abrogation of their responsibility in providing the needed resources towards ensuring that every child has access to quality education.

The inadequacy of textbooks was one of the reasons found from the study which hamper students' academic performance. Government, through the Ministry of education and the Ghana Education Service (GES), has the responsibility to ensure that textbooks are adequately provided for schools but this has not been the case. This inadequacy of resource provision reemphasizes governments' apathetic attitude towards promoting children's accessibility to quality education. In the findings of Pscharopolus \& Woodhall, (1985), the availability of adequate textbooks is very vital in governments' efforts to promote quality education for the people. Chepchieng (1995) reiterated that students' performance rate is positively related to the availability of textbooks. Although Chepchieng (1995) agrees 
that it is necessary for students to have textbooks, those textbooks need to be of good quality, accessible and adequate.

Evidence also exists to the fact that, every child needs a conducive school environment to study (Roman \& Murrillo, 2011; Branham, 2005). One of such is the provision of adequate school infrastructure and other facilities. In Ghana, the local and central governments have the responsibility to provide school infrastructure. In the last few years a number of NGOs and other interested stakeholders have tried to fill some of the gaps in this area by assisting in providing some temporary school infrastructures or rehabilitating some dilapidated ones. These, though cannot be the permanent or sustainable solutions to the problem because these efforts of the private sector are not well coordinated. The absence of school infrastructure and the deplorable nature of those available (with cracked and dangerous walls, no ceiling and leaked roofings affected teaching and learning. This is partly the reason for the massive failure of students at the Basic Education Certificate Examination in many of the rural communities in Ghana as mirrored by those schools surveyed in this study. Branham's (2005) study concluded that if school districts wish to maximize attendance and minimize drop-out rates, they should put premium on building permanent, conducive school infrastructure. This applies so much to the Ghanaian context that if government wants to improve the performance of students then its commitment to infrastructural development in schools should be paramount and transparent.

Inadequate and inequitable placement or posting of professional teachers was found to be a major factor to successful performance of students. As, enumerated over and over again by the participants in this study, this problem emanates from governments' inability to properly prioritize or allocate resources towards the training of teachers and promoting quality education in general. Government is solely responsible for the training and posting of teachers across the country. The school management, more especially those in the northern part of the country and the sampled rural schools, lamented the absence of adequate trained or professional teachers in their various schools. This problem raises two strategic questions; either there are not enough trained teachers or the trained teachers are not distributed equitably and thus unfavourable to some schools.

\section{Recommendations}

Reversing the drop-out, push-out dilemma and phenomenon of poor quality education in the Junior High School sector of Ghana's education system will require serious commitment and investment from government and society into the education system. The following recommendations are therefore made in response to the problems revealed by the study for the effective performance of the JHS system in Ghana.

- Adequate preparation in terms of human and material resources should be made before any intervention is embarked on. This should include the training and re-training of pre-technical and pre-vocational skills teachers who should be posted to all schools.

- Parents, children and community members should be educated to understand the importance of education and hence commit resources to their children's education

- Teachers should be well motivated especially those in rural areas. This will make them effective and give off their best

- Government should be more committed to the education of the country's youth by providing enough resources in terms of infrastructure, text books, and teachers among others, to all JHS in Ghana

The above and many other recommendations, if well enforced, will make the JHS system in Ghana very effective and functional to provide the much-needed skills for the thousands of youth who fill the JHS classrooms every year.

\section{Conclusion}

The high drop-out rates in the JHS system and its attendant failure to provide quality education to the children of Ghana severely limit the chances and opportunities for success for far too many children in the country. It deepens and fuels the cycle of poverty into future generations. Ghana's future surely depends on the delivery of a high quality education to its children and especially those from the rural areas of the country who are in the majority. Children are entitled to quality education regardless of the socio-economic status of their families or whichever part of the country they live.

In conclusion we have seen that educational policies, resource infusion and management, and curriculum decisions have always influenced the retention or attrition of students in Ghana's educational system. The national goal should be to open the dropout problem not only to teachers but also parents, students, other citizens in the community and most importantly government and other vital stakeholders who are committed to resource equity and excellence for all Ghanaian youth in the pursuit of educational achievement. 
Finally, if Ghanaian society truly wants to rescue the sinking educational ship currently wallowing in a quagmire of hopelessness and provide effective voice to the millions of children and youth of the country, Ghanaian society needs to provide an educational structure or system whose curriculum and culture are appropriate and relevant to the needs of the future generation of this country. This is absolutely necessary in the face of the current globalization era where the world is so inter-twined and inter-connected that any youth without sound education and skills will have virtually no future.

\section{References}

Ainsworth, M., K. Beegle, \& G. Koda (2005). The impact of adult mortality and parental deaths on primary schooling in North-Western Tanzania. The Journal of Development Studies 41(3):412:439.

Akyeampong, K., J. Djangmah, A. Seidu, A. Oduro, \& F. Hunt (2007) Access to Basic Education in Ghana: The Evidence and the Issues. CREATE Country Analytic Report. Sussex: CREATE.

Astone, N. M., \& McLanahan, S. S. (1991). Family structure, parental practices, and high school completion [Electronic version]. American Sociological Review, 56, 309-320.

Berg, B. L. (2001). Qualitative research methods for the social science. Needham heights, MA: Allyn \& Bacon

Branham, D. (2005). The wise man builds his house upon the rock: The effects of inadequate school building infrastructure on student attendance. Retrieved from www. attendanceworks.org/.../Effects-of-Inadequate-Building-Infrastruct on 8/8/2013.

Carbonaro, W. J. (1998). A little help from my friends' parents: Intergenerational closure and educational outcomes [Electronic version]. Sociology of Education, 71, 295-313.

Coleman, J. S. (1987). Families and schools [Electronic version]. Educational Researcher, 16(6), 32-38.

Coleman, J. S. (1988). Social capital in the creation of human capital [Electronic version]. The American Journal of Sociology, 94, S95S120.

Case, A. \& Ardington, C. (2004). Socioeconomic Factors. Demographic and Health Events, Monograph Series, Africa Centre for Health and Population Studies.

Chepchieng, M. C. (1995). Influence of family socio-economic background and gender on student academic performance. A study of secondary schools in Kabartonjo Division. MPhil Thesis, Moi University, Eldoret.

Chitiavi, M.J., 2002. Guidance and Counseling Series -School administration. Nairobi: Kenya Pavement Publishers.

Connelly, R. \& Zheng, Z. (2003). Determinants of school enrollment and completion of 10 to 18 year olds in China. Economics of Education Review, 22(4), 379-388.

Creswell, J. W. (2009). Research design: Qualitative, quantitative and mixed methods approaches. (3rd Ed.). Los Angeles: Sage Publications, Inc.

Duryea, S. (2003). School attendance, child labor and local labor market fluctuations in urban Brazil. World Development, 31(7), 11651178.

Earthman, G.I. (2004). Prioritization of 31 criteria for school building adequacy. Baltimore, MD: American Civil Liberties Union Foundation of Maryland.

Education Reform (2007). Education Reform 2007 at a Glance. Retrieved on 20/07/2013 from http://www.moess.gov.gh.

Epstein, J. L., \& Sheldon, S. B. (2002). Present and accounted for: Improving student attendance through family and community involvement. The Journal of Educational Research, 95, 308-318.

Ersado, L. (2005). Child labor and schooling decisions in urban and rural areas: Comparative

evidence from Nepal, Peru, and Zimbabwe. World Development, 33(3), 455---480.

Etsey, K. (2005). Causes of low academic performance of primary school pupils in the Shama Sub-metro of Shama Ahanta East Metropolitan Assembly in Ghana. A paper presented at the Regional conference on education in West Africa held in Dakar, Senegal on $1^{\text {st }}$ and $2^{\text {nd }}$ Novermber, 2005. Retrieved from www.saga.cornell.edu/saga/educconf/etsey.pdf on 31/07/2013.

Farrant, J. S. (1980). Principles and practice of education. London, England: English Language Book Society.

Fisher, D. (2001). "We're moving on up": Creating a schoolwide literacy effort in an urban high school. Journal of Adolescent \& Adult Literacy, 45, 92-103.

Frimpong, J. (2000). Funding education in Ghana, another view. Daily Graphic, Tuesday January 4th, 2000, p.7.

Greenberg, M., Weissberg, R., Obrien, M., Zins, J., Fredericks, L., Resnik, H., \& Elias, M. (2003). Enhancing school-based prevention and youth development through coordinated social, emotional, and academic learning. American Psychologist, 58(6/7), 466-474.

Gubert, F. and Robilliard, A. (2006) Do Household Income Shocks Affect School Attendance in Rural Areas?: A case study of Madagascar. Working Paper. Paris: Development, Institutions \& Analyses de Long terme.

Haines, M. M., Stansfeld, S. A., Job, R. F. S., Berglund, B. \& Head, J. (2001). Chronic aircraft noise exposure, stress responses, mental health and cognitive performance in school children. Psychological Medicine, 31, 265-277.

Hofferth, S. L., Boisjoly, J., \& Duncan, G. J. (1998). Parents' extrafamilial resources and children's school attainment [Electronic version]. Sociology of Education, 71, 246-268.

Hollway, W. \& Jefferson, T. (2000). Doing qualitative research differently: Free association, narrative and the interview method. London: Sage.

Israel, G. D., \& Beaulieu, L. J. (2004). Investing in communities: Social capital's role in keeping youth in school [Electronic version]. Journal of the Community Development Society, 34(2), 35-57. 
McNeal, R. B., Jr. (1999). Parental involvement as social capital: Differential effectiveness on science achievement, truancy, and dropping out [Electronic version]. Social Forces, 78, 117-144.

Marshall, C. \& Rossman, G. B. (2006). Designing qualitative research (4th ed.). Thousand Oaks, Ca: Sage Publications, Inc.

Maxwell, L. E. \& Evans, G.W. (2000). The effects of noise on pre-school children's pre-reading Skills. Journal of Environmental Psychology, 20, 91-97.

Mbugua, Z. K. , Kibet, K., Muthaa, G. M., \& Nkonke, G. R. (2012). Factors contributing to students' performance in mathematics at Kenya Certificate of Secondary Education in Kenya: A case of Baringo County, Kenya. American International Journal of Contemporary Research, 2(6), 85-91.

Ministry of Education (1999). A decade of educational reforms: preparation for the challenges of the millennium. A national education forum working document. A background paper prepared for the ministry of education by the forum technical team.

MoE (2002). Ministry of Education, Report of the President's Committee on Review of Education Reforms in Ghana (Anamuah-Mensah Report), Ministry of Education, Accra.

Munda, S. W., Tanui, E. K., \& Kaberia, L. (2000). Relationship between selected education facilities and students' academic performance in secondary schools in Bungoma District, Kenya. Kenya Journal of Education Planning, Economics and Management, Eldoview Graphics, Kakamega, Kenya.

Ocansey, R., Seidu, S. \& Jatong, J. (2013). Physical education and after-school sport programs in Ghana: The role of public and private structures. In J. R. Chepyator-Thomson and Shan-Hui Hsu (Eds). Global perspectives on physical education and after-school sports (pp. 13-35). Lanham, MD: University Press of America.

Okyerefo, M.P.K., Fiaveh, D.Y. \& Lamptey, S.N.L. (2011). Factors prompting pupils' academic performance in privately owned Junior High schools in Accra, Ghana. International journal of sociology and anthropology, 3(8), pp. 280-289.

Psacharopoulus, G. \& Woodhall, M. (1985). Education for Development. An analysis of development choices. Washington, D. C.: Oxford University Press.

Roman, F. J. \& Murrillo, M. (2011). School effectiveness and school improvement. Internationa Journal of Research, Policy and Practice, 22(1), 29-50.

Schneider, M. (2002). Do school facilities affect academic outcomes? National Clearinghouse for Educational Facilities. Retrieved from http://www.edfacilities.org/pubs/outcomes.pdf on 31/07/2013.

Townsend, T. (1999). The third millennium school: Towards a quality education for all students. Seminar Series no. 81, Melborne: IARTV.

WAEC (1990). Chief examiners report. Retrieved from http://www.ghanawaec.org/EXAMS/ChiefExaminersReport.aspx on $5^{\text {th }}$ November, 2012. 